\title{
Identifikasi dan Efektivitas Berbagai Teknik Pengendalian Hama Baru Ulat Grayak Spodoptera frugiperda J. E. Smith pada Tanaman Jagung Berbasis PHT-Biointensif
}

\section{(Identification and Effectiveness of Various Control Techniques of Fall Armyworm Spodoptera frugiperda J. E. Smith on Corn Plants with Biointensive IPM-Based)}

\author{
Rizki Darmawan Septian ${ }^{1 *}$, Lutfi Afifah ${ }^{1}$, Tatang Surjana ${ }^{1}$, Nurcahyo Widyodaru Saputro ${ }^{1}$, Ultach Enri ${ }^{2}$
}

(Diterima Desember 2020/Disetujui Juli 2021)

\begin{abstract}
ABSTRAK
Keberadaan hama baru Spodoptera frugperda J. E. Smith berpotensi dalam menurunkan produksi jagung sehingga keberadaannya perlu untuk dikendalikan. Tujuan penelitian ini ialah untuk mendapatkan teknik pengendalian yang dapat menekan intensitas serangan hama $S$. frugiperda. Penelitian dilaksanakan pada bulan Juni hingga Oktober 2020. Rancangan penelitian yang digunakan adalah Rancangan Acak Kelompok (RAK) dengan 9 ulangan dan 3 perlakuan yang terdiri atas: non-pengendalian (NP), PHT-biointensif (BI), dan pestisida sintetik. Pada perlakuan BI digunakan ekstrak daun mimba $(25 \mathrm{~mL} / \mathrm{plot})$ dan Beauveria bassiana $(6,25 \mathrm{~g} / \mathrm{plot})$. Sementara itu, pada perlakuan PS digunakan bahan aktif deltametrin $(3,125 \mathrm{~mL} / \mathrm{plot})$. Volume semprot yang digunakan adalah $1,25 \mathrm{~L}$. Hasil penelitian menunjukkan bahwa teknik pengendalian PS memberikan hasil terbaik dalam menekan intensitas serangan hama ulat grayak S. frugiperda (0,57\%-7,04\%) diikuti oleh perlakuan BI (0\%-6,89\%) dan NP (0,97\%-8,29\%). Populasi hama tertinggi secara keseluruhan terdapat pada perlakuan NP dan terendah pada perlakuan PS. Perlakuan PS memberikan hasil produksi tertinggi dengan bobot tongkol sebesar $18,56 \mathrm{~kg} /$ petak $(24,81 \mathrm{ton} / \mathrm{ha})$, sedangkan perlakuan BI sebesar $17,00 \mathrm{~kg} /$ petak $(22,72$ ton/ha) dan NP sebesar $15,44 \mathrm{~kg} /$ petak $(20,64 \mathrm{ton} / \mathrm{ha})$. Hasil uji korelasi antara intensitas serangan hama dan hasil produksi menunjukkan bahwa semakin tinggi serangan hama, maka semakin rendah bobot panen yang dihasilkan. Dengan demikian, pengendalian hama dengan menggunakan pestisida sintetik berbahan aktif deltametrin dinyatakan efektif dalam menekan intensitas serangan dan populasi hama ulat grayak S. frugiperda serta mampu memberikan hasil produksi yang tinggi.
\end{abstract}

Kata kunci: intensitas serangan, jagung, Spodoptera frugiperda

\section{ABTRACT}

The presence of new pest Spodoptera frugperda J. E. Smith has the potential to reduce corn production, so its existence needs to be controlled. The aim of this research is to obtain control techniques that could reduce the intensity of $S$. frugiperda pest's attack. The research was conducted from June to October 2020. The experiment was designed in a randomized block design (RBD) with 9 replications and 3 treatments consisting of non-control (NP), PHT-biointensive (BI), and synthetic pesticides. In BI treatment, neem leaf extract $(25 \mathrm{~mL} / \mathrm{plot})$ and Beauveria bassiana (6,25 g/plot) were used. Meanwhile, the PS treatment used deltametrin active ingredient (3,125 $\mathrm{mL} / \mathrm{plot})$. The volume of spray used was $1,25 \mathrm{~L}$. The results showed that PS control techniques gave the best results in suppressing the intensity of fall armyworm S. frugiperda attacks $(0,57 \%-7,04 \%)$ followed by $\mathrm{BI}$ treatment $(0 \%-6,89 \%)$ and NP $(0,97 \%-8,29 \%)$. The highest pest populations overall were found in NP treatment and the lowest in PS treatment. PS treatment provided the highest production result with a cob weight of $18,6 \mathrm{~kg} / \mathrm{plot}(24,81$ tons/ha), while $\mathrm{BI}$ treatment of $17,00 \mathrm{~kg} / \mathrm{plot}(22,72 \mathrm{tons} / \mathrm{ha})$ and NP of $15,44 \mathrm{~kg} / \mathrm{plot}(20,64$ tons/ha). The results of the correlation test between the intensity of pest attacks and production results showed that the higher the pest attack, the lower the harvest weight produced. Therefore, pest control by using synthetic pesticides made from active deltametrin is declared effective in suppressing the intensity of attacks and populations of fall armyworm $S$. frugiperda and able to provide high production results.

Keywords: corn, intensity of attack, Spodoptera frugiperda

1 Program Studi Agroteknologi Fakultas Pertanian Universitas Singaperbangsa, JI. HS. Ronggo Waluyo, Puseurjaya, Karawang, Jawa Barat, 41361

2 Program Studi Teknologi Informasi Fakultas IImu Komputer Universitas Singaperbangsa, Jl. HS. Ronggo Waluyo, Puseurjaya, Karawang, Jawa Barat, 41361

*Penulis Korespondensi: E-mail: rizkidseptian@gmail.com

\section{PENDAHULUAN}

Jagung merupakan salah satu komoditas pangan yang penting kedua setelah padi dan menjadi prioritas utama dalam meningkatkan ketahanan pangan di Indonesia. Akan tetapi, dalam upaya pengembangannya masih terdapat kendala salah satunya adalah 
faktor biotik, yaitu tingginya serangan hama dan penyakit (Fattah \& Hamka 2011).

Ulat grayak (Spodoptera frugiperda J.E. Smith) merupakan serangga daerah tropis yang berasal dari Amerika Serikat hingga Argentina. S. frugiperda dianggap sebagai hama berbahaya karena mampu menyerang lebih dari 80 spesies tanaman, salah satunya adalah tanaman jagung. Hama ini dapat mengakibatkan kehilangan hasil yang signifikan apabila penanganan yang dilakukan tidak tepat (Kementan 2019). Di negara Afrika dan Eropa, kerugian akibat serangan hama ini mencapai 8,3-20,6 juta ton per tahun dengan nilai kerugian ekonomi antara US\$ 2,5-6,2 milyar per tahun (FAO \& CABI 2019).

Ulat grayak $S$. frugiperda telah dilaporkan masuk ke Indonesia, tepatnya di Kabupaten Pasaman Barat, Sumatera Barat pada awal tahun 2019. S. frugiperda ditemukan merusak tanaman jagung dengan tingkat serangan yang berat dan populasi larva yang berkisar antara 2-10 ekor pertanaman. Sampainya hama ini di Indonesia berkaitan dengan karakteristik imagonya yang khas, yaitu dapat terbang hingga $100 \mathrm{~km}$ dalam satu malam (Kementan 2019).

Penelitian yang dilakukan oleh Maharani et al. (2019) juga telah melaporkan bahwa S. frugiperda ditemukan di Provinsi Jawa Barat, tepatnya di Kabupaten Bandung, Kabupaten Garut, dan Kabupaten Sumedang. Penelitian yang dilakukan pada bulan Juni hingga Juli 2019 tersebut menemukan hama $S$. frugiperda yang menyerang tanaman jagung pada umur muda (vegetatif) hingga fase pembungaan (generatif). Populasi hama yang cukup tinggi terdapat di Kabupaten Sumedang, sedangkan untuk Kabupaten Bandung dan Kabupaten Garut populasi hama tersebut masih rendah. Hal ini juga memungkinkan bahwa S. frugiperda telah sampai di Kabupaten Karawang.

Adanya hama baru yang berpotensi dalam menurunkan produksi jagung menyebabkan perlu adanya solusi pengendalian yang tepat sehingga keberadaan hama menjadi tidak merugikan. Dalam upaya mengatasi serangan hama pada tanaman jagung, umumnya petani masih menggunakan pestisida sintetik dengan harapan hasil produk pertanian dapat meningkat. Penggunaan pestisida sintetik semakin meningkat dari tahun ke tahun. Akan tetapi, tingginya penggunaan pestisida tidak diimbangi dengan tingkat pemahaman petani dalam mengaplikasikannya. Dengan demikian, penggunaan pestisida yang tidak tepat mengakibatkan terjadinya pencemaran air, tanah, udara, dan berpengaruh pada kesehatan petani, keluarga petani, serta konsumen lainnya (Yunarti et al. 2013).

Pestisida sintetik dengan bahan aktif deltametrin merupakan pestisida yang sering digunakan oleh petani dalam mengendalikan hama ulat grayak Spodoptera litura. Hal ini dikarenakan bahan aktif deltametrin memiliki efektivitas yang cukup tinggi dalam menekan intensitas serangan hama ulat grayak. Menurut Sastrosiswojo et al. (1989) pestisida sintetik dengan bahan aktif Betasiflutrin, Imidakloprid, dan Deltametrin dapat berpengaruh pada perkembangan serangga. Jika pestisida ini diaplikasikan secara intensif maka dapat membunuh serangga tersebut.

Adanya dampak negatif yang ditimbulkan akibat penggunaan pestisida yang tidak bijaksana, maka petani perlu disadarkan untuk mulai menerapkan sistem PHT (pengendalian hama terpadu) sehingga dapat menurunkan penggunaan pestisida. Pengendalian hama terpadu biointensif (PHT-biointensif) merupakan salah satu solusi atas masalah hama yang semakin berat dari tahun ke tahun. Salah satu strategi PHT-biointensif yang dapat dilakukan antara lain adalah seperti penggunaan agen hayati dan biopestisida (Widjayanti 2012).

Pemanfaatan pestisida nabati dan cendawan entomopatogen dapat menjadi solusi dalam usaha pengendalian hama ulat grayak tanpa merusak ekosistem pertanian. Menurut Indianti dan Marwoto (2008), serbuk biji mimba berpotensi untuk mengendalikan hama kutu kebul (Bemisia tabaci), ulat grayak ( $S$. litura), dan penggerek polong (Maruca testulalis) pada tanaman kacang-kacangan. Rosmiati et al. (2018) juga mengatakan bahwa penggunaan cendawan $B$. bassiana efektif dalam mengendalikan larva S. litura. B. bassiana mampu tumbuh pada tubuh larva kemudian mengeluarkan enzim dan toksin yang dapat menurunkan aktivitas makan larva. Penurunan aktivitas makan larva disebabkan oleh terganggunya jaringan tubuh larva oleh infeksi $B$. bassiana.

Penelitian mengenai teknik pengendalian hama $S$. frugiperda belum banyak dilaporkan. Dengan demikian, perlu dilakukan penelitian mengenai pengaruh beberapa teknik pengendalian pada intensitas serangan hama $S$. frugiperda dengan harapan dapat menjadi solusi pengendalian bagi petani.

\section{METODE PENELITIAN}

\section{Tempat dan Waktu}

Penelitian ini dilaksanakan di lahan percobaan Peruri, Kecamatan Telukjambe Timur, Kabupaten Karawang. Waktu pelaksanaan penelitian dilakukan pada bulan Juni sampai dengan Oktober 2020.

\section{Metode Penelitian}

Penelitian ini menggunakan Rancangan Acak Kelompok (RAK) dengan 9 kali ulangan dan 3 perlakuan yang terdiri atas non-pengendalian (NP), PHT-biointensif (BI), dan pestisida sintetik. Dosis dan waktu aplikasi perlakuan disajikan pada Tabel 1. Pada saat aplikasi perlakuan, setiap petak ditutup menggunakan terpal plastik dengan tinggi $2 \mathrm{~m}$ untuk menghindari adanya percikan pestisida pada perlakuan lain. Penelitian ini menggunakan benih jagung manis varietas Bonanza 9 F1. Petak percobaan 
Tabel 1 Dosis dan waktu aplikasi masing-masing perlakuan

\begin{tabular}{|c|c|c|c|c|c|c|c|c|c|c|c|c|}
\hline \multirow{2}{*}{ Perlakuan } & \multirow{2}{*}{ Bahan aktif } & \multirow{2}{*}{ Dosis } & \multirow{2}{*}{$\begin{array}{l}\text { Volume } \\
\text { semprot }\end{array}$} & \multicolumn{9}{|c|}{ Waktu aplikasi } \\
\hline & & & & 1 & 2 & 3 & 4 & 5 & 6 & 7 & 8 & 9 \\
\hline Pestisidas sintetik (PS) & Deltametrin & $3,125 \mathrm{~mL} /$ petak & $1,25 \mathrm{~L}$ & $\sqrt{ }$ & $\sqrt{ }$ & $\sqrt{ }$ & $\sqrt{ }$ & $\sqrt{ }$ & $\sqrt{ }$ & $\sqrt{ }$ & $\sqrt{ }$ & $\sqrt{ }$ \\
\hline \multirow[t]{2}{*}{ Biointensif (BI) } & B. bassiana & $6,25 \mathrm{~g} /$ petak & $1,25 \mathrm{~L}$ & $\sqrt{ }$ & - & - & $\sqrt{ }$ & $\sqrt{ }$ & - & 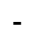 & $\sqrt{ }$ & $\sqrt{ }$ \\
\hline & Azadirachtin & $25 \mathrm{~mL} /$ petak & $1,25 \mathrm{~L}$ & - & $\sqrt{ }$ & $\sqrt{ }$ & - & - & $\sqrt{ }$ & $\sqrt{ }$ & - & - \\
\hline Non pengendalian (NP) & - & - & - & - & - & - & - & - & - & - & - & - \\
\hline
\end{tabular}

berukuran $5 \times 5 \mathrm{~m}$ dengan jarak antarpetak adalah 1,5 $\mathrm{m}$. Total semua petak percobaan adalah 27 petak. Jumlah sampel yang diamati setiap petak percobaan sebanyak 10 tanaman dengan formasi diagonal.

Data dosis yang digunakan pada masing-masing perlakuan diperoleh dari konsentrasi rekomendasi pada setiap kemasan produk. Konsentrasi rekomendasi Deltametrin adalah $2,5 \mathrm{~mL} / \mathrm{L}$ sehingga setiap petak perlakuan memperoleh dosis $3,125 \mathrm{~mL} /$ petak. Pada perlakuan $B$. Bassiana, konsentrasi rekomendasinya adalah $5 \mathrm{~g} / \mathrm{L}$ sehingga setiap petak perlakuan mendapatkan 6,25 g/petak. Sementara itu, pada perlakuan Azadirachtin, konsentrasi rekomendasi adalah sebesar $20 \mathrm{~mL} / \mathrm{L}$ sehingga setiap petak perlakuan mendapatkan dosis $25 \mathrm{~mL} /$ petak. Masingmasing perlakuan diencerkan dengan air sebanyak 1,25 L. Kemudian, perlakuan diaplikasikan dengan cara disemprotkan pada bagian daun tanaman atau bagian yang memungkinkan adanya hama.

\section{Pengamatan Intensitas Serangan Hama}

Pengamatan intensitas serangan hama ulat grayak dilakukan sejak tanaman berumur 1 MST sampai 10 MST dengan interval 7 hari. Pengamatan populasi dilakukan dengan mengamati 10 tanaman sampel yang telah dipilih secara diagonal kemudian menghitung jumlah ulat grayak yang terdapat pada tanaman sampel. Menurut Hendrival et al. (2013), untuk intensitas serangan hama tersebut dihitung berdasarkan gejala yang muncul pada tanaman contoh yang diamati dengan rumus:

$$
I=\sum_{1=1}^{5} \frac{\left(n_{i} \times v_{i}\right)}{Z N} \times 100 \%
$$

\section{Keterangan:}

$\mathrm{n}$ : jumlah daun dalam tiap kategori serangan (1-4)

$\mathrm{v}$ : nilai skala dari tiap kategori serangan

$\mathrm{Z}$ : nilai skala dari kategori serangan tertinggi

$\mathrm{N}$ : jumlah daun yang diamati

Nilai skala untuk tiap kategori serangan hama $S$. frugiperda menurut Hendrival et al. (2013) disajikan pada Tabel 2.

\section{Analisis Data}

Data yang diperoleh dianalisis dengan analisis varians (ANOVA). Jika hasil analisis sidik ragam menujukkan adanya pengaruh yang berbeda nyata (signifikan), data diuji lanjut dengan menggunakan uji beda nyata terkecil (BNT) pada taraf nyata $5 \%$.

\section{HASIL DAN PEMBAHASAN}

\section{Hasil Identifikasi Ulat Grayak (S. frugiperda)}

Hasil pengamatan menggunakan mikroskop menunjukkan adanya beberapa ciri khusus pada larva ulat grayak (Spodoptera frugiperda). Larva ulat grayak instar pertama berwarna kehijauan dengan kepala berwarna hitam. Sementara itu, pada larva instar akhir memiliki kepala berwarna abu-abu gelap dan tubuh abu-abu kusam. Pada bagian kepala larva dewasa terdapat bentukan $Y$ terbalik berwarna putih (Gambar 1A). Pada bagian tubuh terdapat bintik hitam yang membentuk persegi pada abdomen segmen ke-8 dan membentuk trapesium pada segmen ke-9 (Gambar 1B) (Shylesha et al. 2018). Selain itu, terdapat tiga garis kuning di bagian atas tubuh larva (Gambar 1C). Setiap bintik hitam pada tubuh larva memiliki rambut pendek (Gambar 1D) (Kementan 2019). Memiliki empat pasang tungkai palsu (proleg) pada bagian abdomen (Gambar 1E), serta pinacula berwarna gelap pada bagian dorsal (Gambar 1F) (Maharani et al. 2019).

\section{Gejala Kerusakan Tanaman oleh Ulat Grayak (S. Frugiperda)}

Larva muda biasanya makan di bagian bawah permukaan daun. Bagian daun yang dimakan biasanya berwarna semitransparan (windows) (Gambar 2A). Selain itu, bekas gerekan larva menyebabkan adanya serbuk kasar menyerupai serbuk gergaji pada permukaan atas daun atau di sekitar pucuk tanaman jagung (Gambar 2B). Larva instar akhir dapat menyebabkan kerusakan berat yang sering kali hanya menyisakan tulang daun dan batang tanaman jagung. Jika larva merusak pucuk, daun muda, atau titik tumbuh tanaman, hal ini dapat menyebabkan kematian pada tanaman (Gambar 2C). Pada saat memasuki instar 3-6, larva akan masuk ke bagian yang terlindungi (daun muda yang menggulung) dan membuat kerusakan sehingga calon daun akan berlubang (Gambar 2D). Daun muda yang masih menggulung merupakan tempat favorit di mana larva terlindungi dan berkembang pada makanan favoritnya, yakni daun jagung muda yang empuk. Selain Tabel 2 Nilai skala untuk seitap kategori gejala serangan hama S. Frugiderda

\begin{tabular}{cc}
\hline Skala & Kategori tingkat serangan hama \\
\hline 0 & Tidak ada serangan \\
1 & Luas daun yang dimakan $1-25 \%$ \\
2 & Luas daun yang dimakan $26-50 \%$ \\
3 & Luas daun yang dimakan $51-75 \%$ \\
4 & Luas daun yang dimakan $76-100 \%$ \\
\hline
\end{tabular}


memakan bagian daun tanaman, hama ini juga dapat menyerang bagian tongkol jagung (Gambar 2E) (Kementan 2019).

\section{Intensitas Serangan Hama Ulat Grayak frugipeda)}

Salah satu faktor yang mempengaruhi adanya serangan hama ulat grayak ( $S$. frugiperda) adalah penggunaan varietas hibrida. Menurut hasil pemantauan Balai Besar Peramalan Organisme Pengganggu Tumbuhan (BBPOPT), peningkatan serangan terjadi karena penggunaan varietas hibrida, seperti Pioneer, BISI, NK, dan Nasa 29. Dengan demikian, pada penelitian ini penggunaan varietas hibrida Bonanza 9 F1 juga mempengaruhi tingginya intensitas serangan S. hama.

Efek perlakuan pengendalian OPT pada intensitas serangan hama ulat grayak jagung (S. frugiperda) memberikan pengaruh nyata pada minggu ke-5-10 MST. Pada 5 dan 7 MST, perlakuan NP tidak berbeda nyata dibandingkan dengan $\mathrm{BI}$, namun berbeda nyata dibandingkan dengan PS. Sementara itu, pada minggu
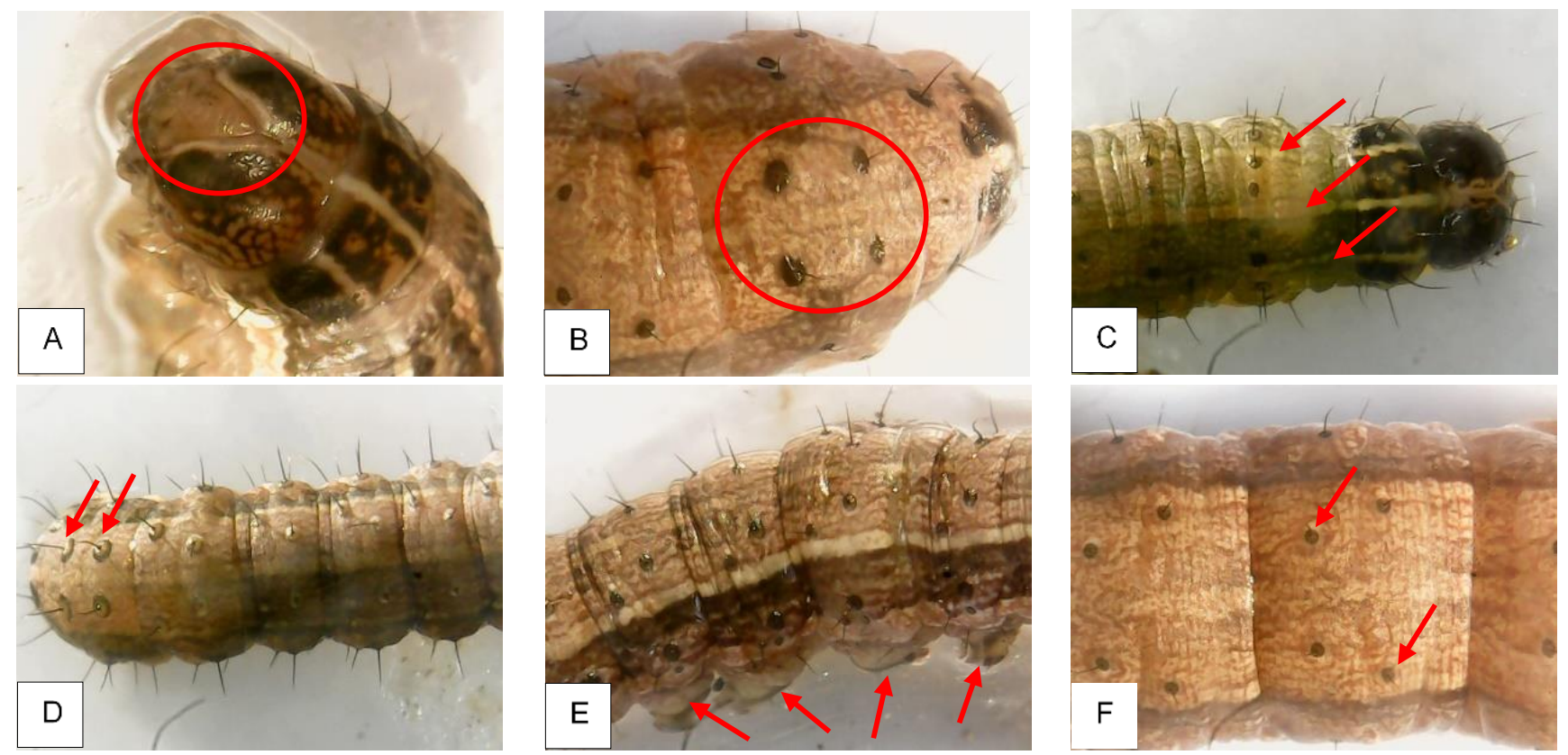

Gambar 1 Morfologi S. frugiperda. (A) huruf $Y$ terbalik di kepala, (B) 4 titik hitam membentuk persegi pada segmen ke-8 dan trapesium pada segmen ke-9, (C) tiga garis kuning di atas tubuh larva, (D) rambut pada setiap penula, (E) empat pasang tungkai, $(F)$ penula berwarna hitam
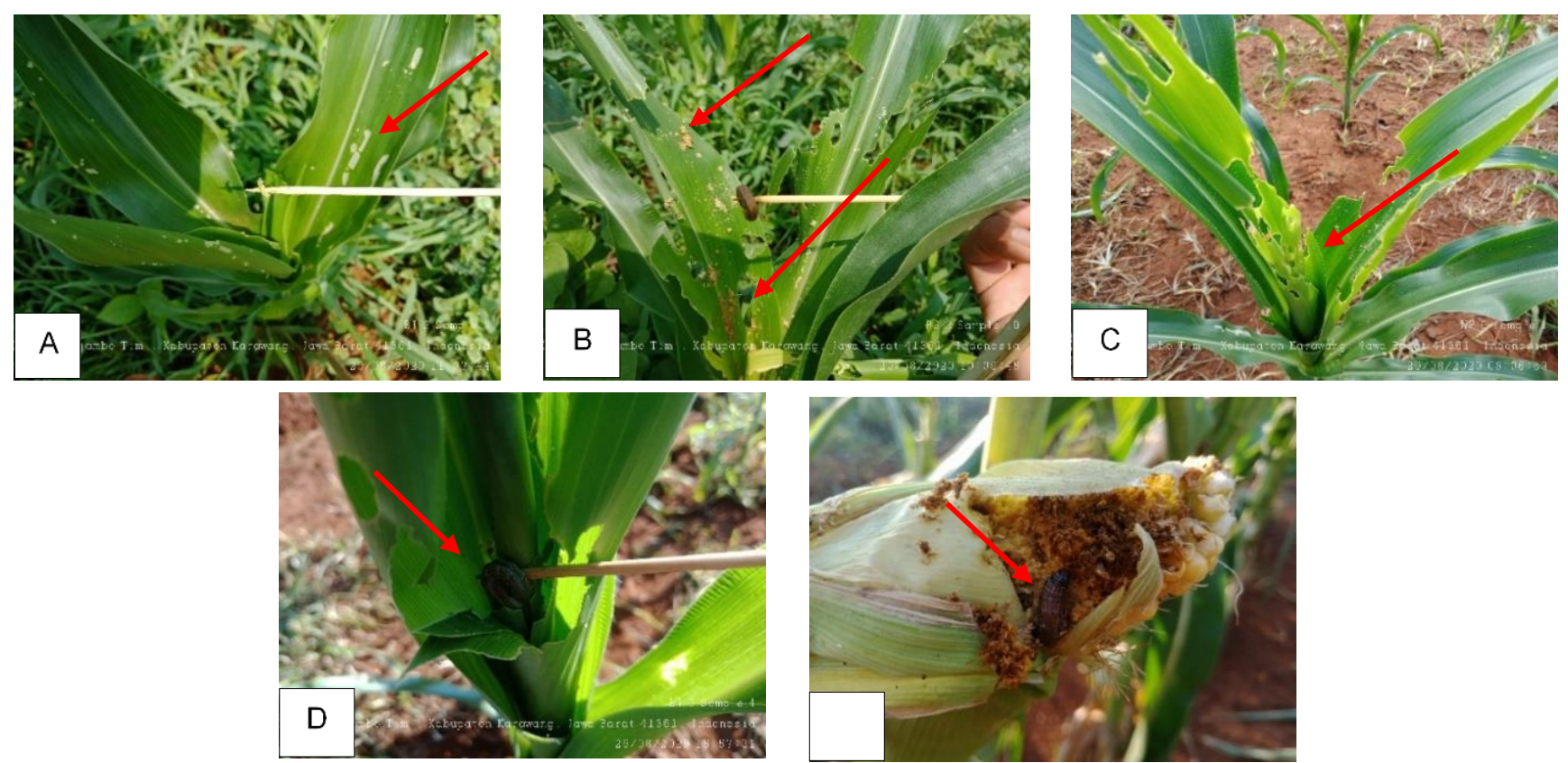

Gambar 2 Gejala kerusakan tanaman. (A) daun terserang berwarna semitransparan (windows), (B) bekas gerekan menyerupai serbuk gergaji, (C) kerusakan pada titik tumbuh tanaman, (D) larva bersembunyi di dalam daun yang menggulung, ( $E$ ) larva menyerang bagian tongkol 
ke-6, 8, 9, dan 10 perlakuan PS memberikan pengaruh terbaik dalam menekan intensitas serangan hama dan berbeda nyata pada perlakuan BI dan NP (Tabel 3).

Intensitas serangan hama yang rendah pada perlakuan PS disebabkan oleh pestisida sintetik berbahan aktif deltametrin yang mampu menekan intensitas serangan dan populasi hama ulat grayak ( $S$. frugiperda). Sastrosiswojo et al. (1989) mengatakan bahwa pestisida sintetik berbahan aktif Betasiflutrin, Imidakloprid, dan Deltametrin berpengaruh pada perkembangan serangga dan apabila diaplikasikan secara intensif maka dapat membunuh serangga tersebut. Menurut Bhanu et al. (2011) Deltametrin merupakan insektisida berspektrum luas yang bertindak sebagai racun kontak dan racun perut. Deltametrin mampu mengendalikan hama dari kelompok Lepidoptera, Hemiptera, Coleoptera, dan Diptera. Deltametrin bekerja dengan cara mem-pengaruhi sistem periferal dan saraf pusat serangga melalui kerja saluran sodium, memperpanjang pembukaan saluran sodium, menstimulasi sel saraf untuk menghasilkan repetitive discharge, yang menyebab-kan paralis (knockdown pada serangga) dan akhirnya serangga mati.

Penggunaan insektisida berbahan aktif yang sama yang dilakukan secara terus menerus dikhawatirkan dapat menimbulkan berbagai masalah yang serius. Hal ini dikarenakan sifat hama yang mempunyai kemampuan untuk berkembang menjadi resistan terhadap insektisida. Masalah resistansi hama terhadap insektisida dapat terjadi apabila petani menggunakan bahan aktif yang sama secara terus menerus sehingga dosis dan frekuensi penggunaan semakin meningkat (Udiarto \& Setiawati 2007). Deltametrin termasuk dalam insektisida piretroid sintetik. Salah satu kelemahan insektisida dari golongan piretroid sintetik adalah cepatnya resistansi hama terhadap golongan ini. Kasus resistansi hama terhadap deltametrin pernah dilaporkan pada tahun 1988 pada hama Plutella xylostella. Walaupun insektisida tersebut relatif baru digunakan pada tanaman kubis, hama $P$. xylostella telah menunjukkan indikasi adanya resistansi (Sastrosiswojo et al. 1989). Hal serupa juga dilaporkan oleh Yu (1991) bahwa hama S. frugiperda mengalami resistansi terhadap insektisida golongan piretroid (permethrin, cypermethrin, cyhalothrin, fenvalerate, tralomethrin, bifenthrin, tetramethrin, dan fluvalinate) yang berkisar antara 2 hingga 216 kali lipat. Dengan demikian, hal tersebut diduga akan menimbu- kan dampak yang sama pada bahan aktif deltametrin terhadap S. frugiperda. Oleh karena itu, PHT (Pengendalian Hama Terpadu) berbasis biointensif masih perlu diutamakan.

Perlakuan BI menunjukkan hasil yang tidak berbeda nyata dibandingkan dengan NP disebabkan oleh pestisida nabati dan agen hayati yang memberikan respons lambat dalam menekan intensitas serangan dan populasi hama ulat grayak ( $S$. frugiperda). Penggunaan azadirachtin dan $B$. bassiana mampu menekan intensitas serangan hama, walaupun penurunan persentase serangan cenderung lebih kecil dibandingkan dengan perlakuan PS. Hal tersebut sesuai dengan hasil yang dilaporkan oleh Rusdy (2009) bahwa ekstrak mimba efektif dalam menekan kerusakan daun yang diakibatkan oleh hama ulat grayak. Sayuthi (2011) juga mengatakan bahwa ekstrak mimba efektif dalam mengendalikan hama ulat grayak ( $S$. litura) sehingga mampu menekan intensitas serangan pada tanaman budi daya. Azadirachtin dapat bertindak sebagai antifeedant, ecdysone blocker, serta penyebab adanya gangguan perkembangan dan reproduksi serangga. Menurut Ramya \& Jayakumararaj (2009) efek antifeedant akan menghasilkan stimulan penolak makan sehingga persepsi rangsangan untuk makan menjadi terganggu. Lebih lanjut Dewi et al. (2017) menyatakan bahwa efek ecdysone blocker menyebabkan serangga terganggu pada proses pergantian kulit, ataupun proses perubahan dari telur menjadi larva, larva menjadi kepompong, dan kepompong menjadi dewasa. Biasanya kegagalan pada proses ini sering kali mengakibatkan kematian serangga.

Cendawan entomopatogen $B$. bassiana diketahui juga mampu mengendalikan hama ulat grayak. Hasil tersebut sesuai dengan hasil yang dilaporkan oleh Nurani et al. (2018) bahwa penggunaan $B$. bassiana pada tanaman tembakau mampu menekan intensitas kerusakan daun yang disebabkan oleh ulat grayak dibandingkan dengan tanpa aplikasi yang dapat mengakibatkan kerusakan daun hingga 95\%. Menurut Karolina et al. (2008), ulat grayak yang terinfeksi oleh $B$. bassiana akan mengalami gangguan metabolisme, sistem pernapasan dan pencernaan sehingga ulat grayak mengalami penurunan nafsu makan dan menjadi kurang aktif. Oleh karena itu, penurunan aktivitas ulat grayak akan berpengaruh pada intensitas kerusakan tanaman.

Tabel 3 Rata-rata intensitas serangan ulat grayak jagung $S$. frugiperda pada 2 MST sampai dengan 10 MST pada tanaman jagung manis varietas Bonanza 9 F1 dengan berbagai teknik pengendalian

\begin{tabular}{ccccccccccc}
\hline \multirow{2}{*}{ Perlakuan } & \multicolumn{8}{c}{ Rata-rata intensitas serangan (\%) MST } \\
\cline { 2 - 10 } & 2 & 3 & 4 & 5 & 6 & 7 & 8 & 9 & 10 \\
\hline PS & $0,57 \mathrm{a}$ & $2,11 \mathrm{a}$ & $7,04 \mathrm{a}$ & $2,82 \mathrm{a}$ & $2,86 \mathrm{a}$ & $2,40 \mathrm{a}$ & $2,06 \mathrm{a}$ & $2,10 \mathrm{a}$ & $2,06 \mathrm{a}$ \\
BI & $0,00 \mathrm{a}$ & $3,73 \mathrm{a}$ & $5,76 \mathrm{a}$ & $5,44 \mathrm{ab}$ & $6,61 \mathrm{~b}$ & $5,84 \mathrm{ab}$ & $6,89 \mathrm{~b}$ & $6,68 \mathrm{~b}$ & $6,55 \mathrm{~b}$ \\
NP & $0,97 \mathrm{a}$ & $4,42 \mathrm{a}$ & $8,05 \mathrm{a}$ & $6,49 \mathrm{~b}$ & $6,70 \mathrm{~b}$ & $7,41 \mathrm{~b}$ & $8,05 \mathrm{~b}$ & $8,29 \mathrm{~b}$ & $8,13 \mathrm{~b}$ \\
\hline
\end{tabular}

Keterangan: Nilai rata-rata yang dinotasikan dengan huruf yang sama pada setiap kolom yang sama menunjukkan bahwa perlakuan tidak berbeda nyata BNT 5\%. MST = minggu setelah tanam; PS = pestisida sintetik; $\mathrm{BI}=$ biointensif; $\mathrm{NP}=$ non pengendalian 
Minggu ke-4 menjadi puncak intensitas serangan hama ulat grayak ( $S$. frugiperda). Hal ini diduga karena pada minggu ke-2 imago pertama kali menemukan inang dan meletakkan telurnya. Seekor ngengat betina dapat bertelur 6 hingga 10 kelompok telur yang terdiri atas 100 hingga 300 butir atau mencapai 1.500 hingga 2.000 telur selama masa hidupnya (Kementan 2019). Dengan demikian, setelah telur menetas pada minggu ke-3 dan ke-4, populasi larva terus bertambah sejalan dengan peningkatan persentase intensitas serangan hama (Gambar 3).

Pada perlakuan NP, intensitas serangan hama menurun pada minggu ke-5, namun terus meningkat hingga $10 \mathrm{MST}$. Hal ini disebabkan tidak adanya teknik pengendalian yang dilakukan pada petak tersebut sehingga intensitas serangan hama dapat terus meningkat hingga menjelang masa panen. Sama halnya dengan perlakuan NP, pada perlakuan BI terjadi penurunan intensitas serangan hama pada minggu ke5 , namun nilai intensitas serangan terus berfluktuasi hingga minggu ke-8 dan stabil menurun pada minggu ke-9 dan 10 walaupun persentase penurunannya relatif kecil. Sementara itu, pada petak PS terjadi penurunan intensitas serangan hama yang sangat signifikan pada minggu ke-5 dan stabil menurun hingga minggu ke-10.

\section{Fluktuasi Populasi Ulat Grayak (S. frugiperda)}

Hama ulat grayak ( $S$. frugiperda) pertama kali muncul pada minggu ke-2 dan terus meningkat secara signifikan hingga minggu ke-4 dengan total ulat grayak yang ditemukan pada petak NP sebanyak 22 ekor, sedangkan pada BI dan PS sebanyak 19 ekor (Gambar 4). Hal ini diduga karena pada minggu ke-2 adalah fase awal ketika imago mulai menemukan inang dan meletakkan telurnya. Kemudian, setelah telur menetas populasi terus meningkat pada minggu ke-3 hingga minggu ke-4. Populasi larva yang tinggi sejalan dengan persentase serangan hama yang tinggi pada minggu ke-4 yang pada perlakuan NP rata-rata intensitas serangan mencapai $8,05 \%$ lebih tinggi dibandingkan dengan perlakuan PS (7,04\%) dan $\mathrm{BI}(5,76 \%)$. Kemunculan hama ini juga diduga karena keadaan lingkungan yang sesuai untuk pertumbuhan dan perkembangannya. Selama masa percobaan, rata-rata suhu harian adalah $31,7^{\circ} \mathrm{C}$. Suhu tersebut cocok untuk perkembangan bagi larva ulat grayak. Hal tersebut sesuai dengan laporan Ali et al. (1990) bahwa kisaran suhu yang cocok untuk perkembangan larva ulat grayak berkisar antara $21-33^{\circ} \mathrm{C}$. Lebih lanjut Plessis et al. (2020) menyatakan kisaran suhu yang sesuai untuk perkembangan larva ulat grayak $S$. frugiperda dari telur hingga imago berkisar antara $26-32^{\circ} \mathrm{C}$. Pada kisaran suhu tersebut, semakin tinggi suhu akan mempengaruhi kecepatan perkembangan larva. Pada suhu $18^{\circ} \mathrm{C}$, periode perkembangan $S$. frugiperda (telur ke dewasa) berlangsung selama 71,44 hari. Sementara itu, pada suhu $32^{\circ} \mathrm{C}$ perkembangan hanya berlangsung selama 20,27 hari. Dengan demikian, pada penelitian ini keadaan suhu yang sesuai mempengaruhi populasi $S$. frugiperda karena proses perkembangannya berlangsung dalam waktu yang lebih cepat.

Populasi larva $S$. frugiperda pada semua perlakuan mulai menurun pada minggu ke-5 hingga minggu ke-7 dan kembali mengalami peningkatan pada minggu ke8 hingga ke-10 (Gambar 4). Pada minggu ke-5 penurunan populasi berkaitan dengan sifat kanibal pada larva S. frugiperda. Menurut Kementan (2019), larva $S$. frugiperda mempunyai sifat kanibal sehingga larva yang ditemukan pada satu tanaman jagung hanya berkisar antara 1-2 ekor per tanaman, dan perilaku kanibal ini dimiliki oleh larva instar 2 dan 3. Penurunan populasi hama pada 6-7 MST berkaitan dengan ketersediaan makanan bagi larva. Menurut Rondo et al. (2016), dinamika populasi hama utama tanaman jagung dipengaruhi oleh stadia pertumbuhan tanaman. Populasi hama akan tinggi apabila kondisi organ tanaman (daun) masih berada pada usia muda yang sesuai dengan peruntukan pakannya. Kemudian, populasi kembali meningkat pada 8-10 MST dikarenakan adanya sumber makanan yang baru, yaitu tongkol jagung. Menurut Kementan (2019), ulat grayak $S$. frugiperda selain menyerang bagian daun tanaman juga dapat meyerang bagian tongkol jagung. Oleh karena itu, ketersediaan sumber makanan yang baru menyebabkan populasi hama menjadi terus meningkat.

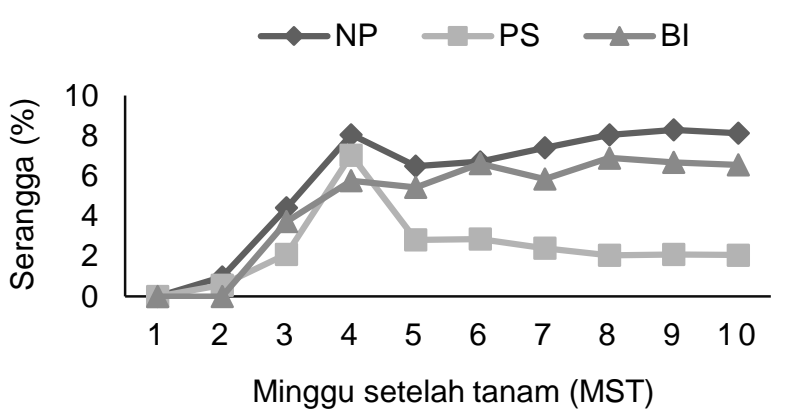

Gambar 3 Intensitas serangan (\%) hama ulat grayak jagung S. frugiperda selama pengamatan 2-10 MST pada petak perlakuan pestisida sintetik (PS), biointensif (BI), dan non-pengendalian (NP)

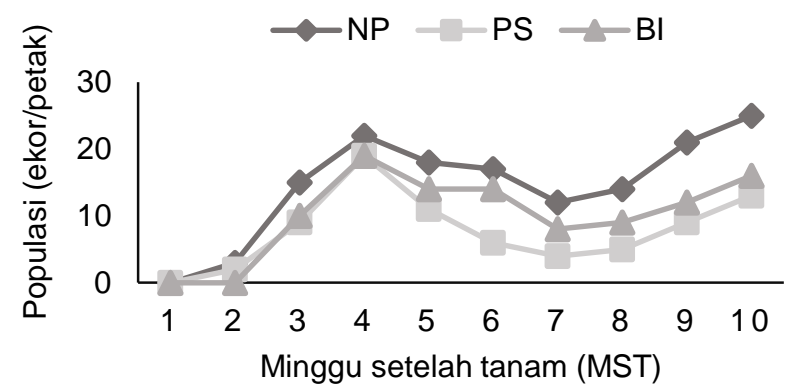

Gambar 4 Kurva jumlah populasi hama ulat grayak jagung $S$. frugiperda selama pengamatan 2-10 MST pada petak perlakuan pestisida sintetik (PS), biointensif (BI), dan non-pengendalian (NP) 


\section{Bobot Tongkol Per Petak}

Perlakuan PS berbeda nyata dibandingkan dengan perlakuan BI dan NP. Perlakuan PS memberikan bobot tertinggi dengan rata-rata bobot tongkol 18,56 $\mathrm{kg} /$ petak, diikuti oleh perlakuan BI dengan bobot 17,00 $\mathrm{kg} /$ petak, dan NP dengan bobot 15,44 kg/petak (Tabel 4). Hasil produksi yang lebih tinggi pada perlakuan PS disebabkan oleh persentase serangan hama yang rendah. Dengan demikian, bobot tongkol yang dihasilkan lebih tinggi dibandingkan dengan perlakuan lainnya.

Menurut Prawiranata et al. (1995), serangan hama akan mempengaruhi hasil produksi karena serangan hama berdampak pada kualitas suatu tanaman. Hal tersebut juga sesuai dengan hasil penelitian Puspitasari et al. (2016) pada tanaman kedelai yang menyatakan bahwa keberadaan hama mempengaruhi pertumbuhan tanaman yang pada akhirnya akan mempengaruhi produktivitas. Pengelolaan hama berbasis PHT, kimiawi, dan non-kimiawi memberikan hasil produksi yang lebih tinggi dibandingkan dengan tanpa pengendalian.

Intensitas serangan hama yang rendah pada perlakuan PS disebabkan oleh pestisida sintetik berbahan aktif deltametrin yang mampu menekan intensitas serangan hama ulat grayak. Hal ini sejalan dengan hasil penelitian Bagariang et al. (2020) yang melaporkan bahwa perlakuan dengan aplikasi pestisida sintetik berbahan aktif klorantraniliprol mampu menekan intensitas serangan hama ulat grayak ( $S$. frugiperda) sehingga memberikan hasil terbaik pada bobot tongkol jagung dibandingkan dengan tanpa aplikasi.

Perlakuan $\mathrm{BI}$ menunjukkan hasil yang lebih tinggi dibandingkan dengan perlakuan NP karena pengaruh aplikasi ekstrak mimba dan $B$. bassiana yang mampu menekan intensitas serangan hama. Hal ini sejalan dengan hasil penelitian Tarigan et al. (2012) pada tanaman sawi yang menyatakan bahwa penggunaan pestisida nabati ekstrak mimba yang dikombinasikan dengan kulit jeruk manis mampu menekan intensitas serangan hama $S$. litura sehingga produksi yang dihasilkan lebih tinggi dibandingkan dengan perlakuan tanpa pengendalian.

Perlakuan NP memberikan hasil produksi paling rendah yang disebabkan oleh intensitas serangan hama yang tinggi dan tidak dilakukannya pengendalian. Ulat grayak ( $S$. frugiperda) selain merusak bagian daun tanaman, hama ini juga dapat menyerang bagian tongkol sehingga apabila tidak dilakukan pengendalian akan menyebabkan penurunan hasil produksi. Menurut Kementan (2019), kepadatan rata-rata populasi $0,2-0,8$ larva per tanaman dapat mengurangi hasil 5-20\%. Selain itu, infestasi ulat grayak pada tanaman jagung pada saat daun muda yang masih menggulung menyebabkan kehilangan hasil $15-73 \%$ jika populasi tanaman terserang $55-100 \%$.

\section{Korelasi Intensitas Serangan Hama dengan Hasil Produksi}

Nilai korelasi menggambarkan hubungan antara variabel serangan hama dengan variabel produksi. Nilai korelasi berkisar antara -1 sampai dengan +1 , semakin mendekati -1 atau +1 maka hubungan $X$ dengan $Y$ semakin kuat atau semakin mendekati sempurna (Prawiranata et al. 1995). Nilai korelasi serangan hama dengan produksi pada penelitian ini adalah negatif (Tabel 5), yang menunjukkan bahwa hubungan antara serangan hama dengan bobot produksi bertolak belakang. Artinya, semakin tinggi intensitas serangan suatu hama, maka akan semakin rendah produksi buahnya.

Nilai korelasi yang negatif pada penelitian ini sesuai dengan penelitian Merta et al. (2017) bahwa semakin tinggi serangan hama maka semakin rendah bobot panen yang dihasilkan. Menurut Prawiranata et al. (1995), tanaman yang terserang hama akan menurunkan bobot buah. Penurunan bobot tersebut dikarenakan tanaman yang daunnya terserang oleh hama akan mempengaruhi laju fotosintesis. Serangan hama ulat grayak jagung ( $S$. frugiperda) pada tanaman mengakibatkan daun berlubang, sehingga luas permukaan daun yang digunakan untuk proses fotosintesis berkurang dan mengakibatkan hasil fotosintat menjadi rendah.

\section{KESIMPULAN}

Teknik pengendalian PS memberikan hasil terbaik dalam menekan intensitas serangan hama ulat grayak S. frugiperda $(0,57 \%-7,04 \%)$ diikuti oleh perlakuan BI

Tabel 4 Rata-rata bobot tongkol per petak pada tanaman jagung manis dengan berbagai teknik pengendalian

\begin{tabular}{ccc}
\hline Perlakuan & Bobot tongkol per petak (kg) & Bobot tongkol (ton/ha) \\
\hline PS & $18,56 \mathrm{a}$ & 24,81 \\
BI & $17,00 \mathrm{~b}$ & 22,72 \\
NP & $15,44 \mathrm{c}$ & 20,64 \\
\hline
\end{tabular}

Keterangan: Nilai rata-rata yang dinotasikan dengan huruf yang sama pada setiap kolom yang sama menunjukkan bahwa perlakuan tidak berbeda nyata BNT $5 \%$. MST = minggu setelah tanam; $\mathrm{PS}$ = pestisida sintetik; $\mathrm{BI}=$ biointensif; NP $=$ non pengendalian

Tabel 5 Koefisien korelasi dan determinasi antara intensitas serangga hama dan bobot produksi

\begin{tabular}{ccc}
\hline Peubah pengamatan & Koefisien korelasi $(r)$ & Nilai determinasi $\left(R^{2}\right)$ \\
\hline Serangan ulat grayak & $-0,023278$ & 0,0005 \\
\hline
\end{tabular}


(0\%-6,89\%) dan NP $(0,97 \%-8,29 \%)$. Populasi hama tertinggi secara keseluruhan terdapat pada perlakuan NP dan terendah pada perlakuan PS. Perlakuan PS memberikan hasil produksi tertinggi dengan bobot tongkol sebesar 18,56 kg/petak (24,81 ton/ha), sedangkan perlakuan $\mathrm{BI}$ sebesar $17,00 \mathrm{~kg} /$ petak (22,72 ton/ha) dan NP sebesar 15,44 kg/petak $(20,64$ ton/ha). Hasil uji korelasi antara intensitas serangan hama dan hasil produksi menunjukkan bahwa semakin tinggi serangan hama, maka semakin rendah bobot panen yang dihasilkan. Dengan demikian, pengendalian hama dengan menggunakan pestisida sintetik berbahan aktif deltametrin dinyatakan efektif dalam menekan intensitas serangan dan populasi hama serta mampu memberikan hasil produksi yang tinggi.

\section{UCAPAN TERIMA KASIH}

Penulis mengucapkan terima kasih kepada Lembaga Penelitian \& Pengabdian Kepada Masyarakat (LPPM) Universitas Singaperbangsa Karawang atas dukungan pendanaan selama kegiatan penelitian melalui skema Hibah Prioritas LPPM Unsika Surat Perjanjian Nomor: 1713.94/SP2H/UN64/LL/2020 Tanggal: 07 Desember 2020.

\section{DAFTAR PUSTAKA}

Ali A, Luttrell RG, Schneider JC. 1990. Effects of temperature and larval diet on development of the fall army worm (Lepidoptera: Noctuidae). Annals of The Entomological Societyof America. 83(4): 725-733. https://doi.org/10.1093/aesa/83.4.725

Bagariang W, Tauruslina E, Kulsum U, Murniningtyas T, Suyanto H, Surono, Cahyana NA, Mahmuda D. 2020. Efektivitas insektisida berbahan aktif klorantraniliprol terhadap larva Spodoptera frugiperda (JE Smith). Jurnal Proteksi Tanaman. 4(1): 29-37. https://doi.org/10.25077/jpt.4.1.29 37.2020

Bhanu S, Archana S, Ajay K, Bhatt JL, Bajpai SP, Singh PS, Vandana B. 2011. Impact of deltamethrin, us as an insecticide and its bacterial degradation-a preliminary study. International Journal of Environmental Sciences. 1(5): 976-985.

Dewi AALN. Karta IW, Wati NLC, Dewi NMA. 2017. Uji efektivitas larvasida daun mimba (Azadirachta indica) terhadap larva lalat Sarcophaga pada daging untuk Upakara Yadnya di Bali. Jurnal Sains dan Teknologi. 6(1): 126-135. https://doi.org/10 $.23887 /$ jst-undiksha.v6i1.9233

[FAO \& CABI] Food and Agriculture Organization, $C A B$ International. 2019. Community-based fall armywarm (Spodoptera frugiperda) monitoring, early warning and management. Training of Trainers Manual, First Edition. Rome (IT) and
Wallingford (UK): Food and Agriculture Organization of the United Nations and CAB International.

Fattah A, Hamka. 2011. Tingkat Serangan Hama Penggerek Tongkol, Ulat Grayak, dan Belalang pada Jagung di Sulawesi Selatan. In: Prosiding Seminar Nasional Serelia; 3-4 Oktober 2011. Maros (ID): Balai Pengkajian Teknologi Pertanian Sulawesi Selatan.

Hendrival, Latifah, Hayu R. 2013. Perkembangan Spodoptera litura F. (Lepidoptera: Noctuidae) pada kedelai. Jurnal Floratek. 8(2): 88-100.

Indianti SW, Marwoto. 2008. Potensi ekstrak biji mimba sebagai insektisida nabati. Buletin Palawija. (15): 9-14.

Karolina E, Mahfud MC, Rahmawati D, Sarwono, Fatimah. 2008. Pengkajian efektivitas cendawan Beauveria bassiana terhadap perkembangan hama dan penyakit tanaman krisan. Di dalam: Prosiding Seminar Nasional Pemberdayaan Petani Melalui Informasi dan Teknologi Pertanian; 16 Juli 2008. Mojosari (ID): Kerjasama BPTP Jatim, Faperta Universitas Brawijaya, Dinas Pertanian Provinsi, Bappeda.

[Kementan] Kementerian Pertanian. 2019. Pengenalan Fall Armywarm (Spodoptera frugiperda J. E. Smith) Hama Baru pada Tanaman Jagung di Indonesia. Jakarta (ID): Balai Penelitian Tanaman Serelia.

Maharani Y, Dewi VK, Puspasari LT, Rizkie L, Hidayat Y, Dono D. 2019. Cases off fall army warm Spodoptera frugiperda J. E. Smith (Lepidoptera: Noctuidae) attack on maize in Bandung, Garut, dan Sumedang District, West Java. Jurnal Cropsaver. 2(1): 38-46. https://doi.org/10.24198/cropsaver.v $2 \mathrm{i} 1.23013$

Merta INM, Darmiati NN, Supartha IW. 2017. perkembangan populasi dan serangan Thrips parvispinus Karny (Thysanoptera: Thripidae) pada fenologi tanaman cabai besar di tiga ketinggian tempat di Bali. Jurnal Agroekoteknologi Tropika. 6(4): 414-422.

Nurani AR, Sudiarta IP, Darmiati NN. 2018. Uji efektivitas jamur Beauveria bassiana Bals. terhadap ulat grayak (Spodoptera litura F.) pada tanaman tembakau. Jurnal Agroekoteknologi Tropika. 7(1): 11-23.

Plessis HD, Schlemmer ML, Berg JVD. 2020. The effect of temperature on the development of Spodoptera frugiperda (Lepidoptera: Noctuidae). Insects. 11(228): 1-11. https://doi.org/10.3390/in sects 11040228

Puspitasari M, Hidayat P, Pudjianto, Marwoto, Rahardjo BT. 2016. Pengaruh pola pengelolaan hama terhadap populasi serangga hama pada lahan kedelai varietas Anjasmoro dan Wilis. Jurnal 
Hama dan Penyakit Tumbuhan Tropika. 16(1): 25-34. https://doi.org/10.23960/j.hptt.11625-34

Prawiranata WS, Harran, Tjandronegoro P. 1995. Dasar-Dasar Fisiologi Tumbuhan II. Bogor (ID): Fakultas Pertanian IPB.

Ramya S, Ja yakumararaj R. 2009. Antifeedant Activity of selected ethnobotanicals used by tribals of vattal hills on Helicoverpa armigera (Hubner). Journal of Pharmacology Research. 2(8): 1414-1418.

Rondo SF, Sudarma IM, Wijana G. 2016. Dinamika populasi hama dan penyakit utama tanaman jagung manis (Zea mays saccharata Sturt) pada lahan basah dengan sistem budidaya konvensional serta pengaruhnya terhadap hasil di Denpasar-Bali. Agrotrop: Journal on Agriculture Science. 6(2): 128-136.

Rosmiati A, Hidayat C, Firmansyah E, Setiati Y. 2018. Potensi Beauveria bassiana sebagai agens hayati Spodoptera litura Fabr. pada tanaman kedelai. Jurnal Agrikultura. 29(1): 43-47. https://doi.org/ 10.24198/agrikultura.v29i1.16925

Rusdy A. 2009. Efektivitas ekstrak mimba dalam pengendalian ulat grayak (Spodoptera litura F.) pada tanaman selada. Jurnal Floratek. 4: 41-54.

Sastrosiswojo S, Koestoni T, Sukwida A. 1989. Status resistensi Plutella xylostella L. Strain Lembang terhadap beberapa jenis insektisida golongan organofosfat, piretroid sintetik dan benzoil urea. Buletin Penelitian Hortikultura. 18(1): 85-93.

Sayuthi M. 2011. Ekstrak biji nimba (Azadirachta indica A. Juss) sebagai insektisida nabati berpotensi terhadap hama ulat grayak (Spodoptera litura F.) di pertanaman kedelai (Glycine max L.). Biospecies. 4(2): 11-17.

Shylesha AN, Jalali SK, Gupta A, Varshney R, Venkatesan T, Shetty P, Ojha R, Ganiger PC, Navik O, Subaharan K, Bakthavatsalam N, Ballal CR, Raghavendra A. 2018. Studies on new invasive pest Spodoptera frugiperda (J. E. Smith) (Lepidoptera: Noctuidae) and Its natural enemies. Journal of Biological Control. 32(3): 145-151.

Tarigan R, Tarigan MU, Oemry S. 2012. Uji efektivitas larutan kulit jeruk manis dan larutan daun nimba untuk mengendalikan Spodoptera litura F. (Lepidoptera: Noctuidae) pada tanaman sawi di lapangan. Jurnal Online Agroteknologi. 1(1): 172-182.

Udiarto BK, Setiawati W. 2007. Suseptibilitas dan kuantifikasi resistensi 4 strain Plutella xylostella L. terhadap beberapa insektisida. Jurnal Hortikultura. 17(3): 277-284

Widjayanti T. 2012. Pengaruh varietas kedelai, mulsa jerami dan aplikasi PGPR terhadap penyakit pustul bakteri dan kelimpahan bakteri rizosfer. [Tesis]. Bogor (ID): Institut Pertanian Bogor.

Yu SJ. 1991. Insecticide resistance in the fall armyworm, Spodoptera frugiperda (J. E. Smith). Pesticide Biochemistry and Physiology. 39(1): 84-91. https://doi.org/10.1016/00483575(91)902 16-9

Yunarti MGC, Widiarnako B, Sunoko HR. 2013. Tingkat Pengetahuan Petani dalam Menggunakan Pestisida. In: Prosiding Seminar Nasional Pengelolaan Sumberdaya Alam dan Lingkungan. Semarang (ID): Universitas Diponegoro. 